\title{
MLXIPL Gene
}

National Cancer Institute

\section{Source}

National Cancer Institute. MLXIPL Gene. NCI Thesaurus. Code C102474.

This gene plays a role in both DNA binding and transcriptional regulation. 